\title{
Tuning of the textural features and acidic properties of sulfated mesoporous lanthana-zirconia solid acid catalysts for alkenylation of diverse aromatics to their corresponding $\alpha$-arylstyrenes
}

\author{
Zhongkui Zhao*, Jinfeng Ran, Yongle Guo, Boyuan Miao, Guiru Wang \\ State Key Laboratory of Fine Chemicals, Department of Catalysis Chemistry and Engineering, School of Chemical Engineering, Dalian University of \\ Technology, Dalian 116024, Liaoning, China
}

A R T I C L E I N F O

Article history:

Received 17 March 2016

Accepted 20 April 2016

Published 5 August 2016

Keywords:

Mesoporous solid acid

Alkenylation

Clean synthesis

Alkenyl aromatics

Textural and acidic properties

Tuning

\begin{abstract}
A B S T R A C T
The textural features and acidic properties of sulfated mesoporous lanthana-zirconia solid acids $\left(\mathrm{SO}_{4}{ }^{2-} /\right.$ meso- $\left.\mathrm{La}_{0.1} \mathrm{Zr}_{0.9} \mathrm{O}_{\delta}\right)$ were efficiently tuned by modifying the conditions used to prepare the meso-La0.1 $\mathrm{Zr}_{0.9} \mathrm{O}_{\delta}$ composites, such as the molar ratio of the template to $\mathrm{La}$ and $\mathrm{Zr}$ metal ions $\left(\mathrm{N}_{\mathrm{t} / \mathrm{m}}\right)$, molar ratio of ammonia to La and $\mathrm{Zr}$ metal ions $\left(\mathrm{N}_{\mathrm{a} / \mathrm{m}}\right)$, hydrothermal temperature ( $T_{\text {hydro }}$ ), and hydrothermal time $\left(t_{\text {hydro }}\right)$. The effect of the textural features and acidic properties on the catalytic performance of solid acid catalysts for alkenylation of $p$-xylene with phenylacetylene was investigated. Various characterization techniques such as $\mathrm{N}_{2}$ physisorption, $\mathrm{X}$-ray diffraction, $\mathrm{NH}_{3}$ temperature-programmed desorption, and thermogravimetric analysis were employed to reveal the relationship between the nature of catalyst and its catalytic performance. It was found that the catalytic performance significantly depended on the textural features and acidic properties, which were strongly affected by preparation conditions of the meso- $\mathrm{La}_{0.1} \mathrm{Zr}_{0.9} \mathrm{O}_{\delta}$ composite. Appropriate acidic sites and high accessibility were required to obtain satisfactory catalytic reactions for this reaction. It was also found that the average crystallite size of $t-\mathrm{ZrO}_{2}$ affected by the preparation conditions had significant influence on the ultrastrong acidic sites of the catalysts. The optimized $\mathrm{SO}_{4}{ }^{2-} / \mathrm{meso}^{-} \mathrm{La}_{0.1} \mathrm{Zr}_{0.9} \mathrm{O}_{\delta}$ catalyst exhibited much superior catalytic activity and coke-resistant stability. Moreover, the developed $\mathrm{SO}_{4}{ }^{2-} /$ meso- $\mathrm{La}_{0.1} \mathrm{Zr}_{0.9} \mathrm{O}_{\delta}$ catalyst demonstrated excellent catalytic performance for alkenylation of diverse aromatics with phenylacetylene to their corresponding $\alpha$-arylstyrenes. Combining the previously established complete regeneration of used catalysts by a facile calcination process with the improved catalytic properties, the developed $\mathrm{SO}_{4}{ }^{2-} /$ meso-La $0.1 \mathrm{Zr}_{0.9} \mathrm{O}_{\delta}$ solid acid could be a potential catalyst for industrial production of $\alpha$-arylstyrenes through clean and atom efficient solid-acid-mediated Friedel-Crafts alkenylation of diverse aromatics with phenylacetylene.
\end{abstract}

(C) 2016, Dalian Institute of Chemical Physics, Chinese Academy of Sciences. Published by Elsevier B.V. All rights reserved.

\section{Introduction}

Friedel-Crafts alkenylation of aromatic compounds has at- tracted a lot of attention owing to its direct, environmentally benign, and atom economic characteristics for the synthesis of alkenyl aromatic compounds that serve as industrially im-

\footnotetext{
* Corresponding author. Tel/Fax: +86-411-84986354; E-mail: zkzhao@dlut.edu.cn

This work was financially supported by the National Natural Science Foundation of China (21276041), the Program for New Century Excellent Talents in University of Ministry of Education (NCET-12-0079), the Natural Science Foundation of Liaoning Province (2015020200), and the Fundamental Research Funds for the Central Universities (DUT15LK41).

DOI: 10.1016/S1872-2067(15)61118-4 | http://www.sciencedirect.com/science/journal/18722067 | Chin. J. Catal., Vol. 37, No. 8, August 2016
} 
portant organic intermediates for dyes, pigments, pharmaceuticals, flavors, agrochemicals, and natural products [1]. The acid-mediated alkenylation of aromatics has been considered a promising approach for the synthesis of alkenyl aromatics owing to its low cost and high activity [2-8].

Solid acid catalysis presents a promising route for diverse acid-mediated organic transformations owing to its key features such as clean reactions, easy separation, catalyst reusability, and applicability in large scale continuous production. Recently, zeolites are more and more regarded as an environmentally benign solid acid catalyst for Friedel-Crafts alkylation in both academic and industrial fields [9-11]. However, in contrast to the Friedel-Crafts alkylation, there are still many challenges that need to be resolved for Friedel-Crafts alkenylation. The biggest challenge is to efficiently prevent the oligomerization and deep polymerization of alkynes resulting from the lower stability of the alkenyl cation species compared with that of the alkyl cation intermediates [12-16]. Until now, there have only been a few reports on alkenylation over solid acid catalysts. Sartori and co-workers [17] published a pioneering work on the alkenylation of aromatics over HSZ-360 zeolite. Unfortunately, the results were not satisfactory, and an irreconcilable contradiction existed between selectivity and catalytic activity: the zeolite catalysts suffered from a calcination process at lower temperature and exhibited high catalytic activity, but it resulted in the formation of a large amount of acetophenone (5\%-20\%); a higher calcination temperature efficiently suppressed the formation of acetophenone along with alkenylation, but it led to a remarkable decrease in catalytic activity. Moreover, the enlargement in scope of substrates is also desirable. The catalytic efficiency of the zeolite-catalyzed alkenylation was not high; $1.0 \mathrm{~g}$ of zeolite was required for transforming less than $1.0 \mathrm{~g}$ of phenylacetylene. The possible reason was that the reaction only took place on the external surface of the catalyst because of the narrow pore channels within the HY zeolite [14,18]. Mesoporous solid acids could be promising candidates for Friedel-Crafts alkenylation. It has previously been demonstrated that a Fe-containing mesoporous aluminosilicate exhibited very high activity for the Friedel-Crafts alkenylation of phenols with aryl-substituted alkynes under mild conditions [19]. However, a further increase in selectivity is desirable.

We have previously developed $\mathrm{H}_{3} \mathrm{PW}_{12} \mathrm{O}_{40}$ (HPA) catalysts supported on MCM-41 for the alkenylation of diverse aromatics [13]. However, further improvement in catalytic activity, selectivity, and expansion in the scope of the reactants is indispensable. Moreover, the complexity and high cost of the preparation process of mesoporous silica limits its potential application in the production of $\alpha$-arylstyrenes using solid acid-catalyzed alkenylation. The supported HPA catalyst on activated carbon was developed to address the high cost issue associated with HPA/MCM-41 [15]. The efficient regeneration of the deactivated catalyst by washing with a polar solvent might require a large amount of evaporable solvent, which would consequently produce an environmental issue in addition to the possible leaching of HPA by the polar solvent. Owing to their relatively high thermal stability and strong acidic sites, sulfated solid super acids have been investigated and used in diverse organic transformations [19-34]. There have only been a few reports of alkenylation over solid superacids. We previously demonstrated that $\mathrm{SO}_{4}{ }^{2-} /$ meso- $\mathrm{La}_{2} \mathrm{O}_{3}-\mathrm{ZrO}_{2}$ could be a promising solid acid catalyst for the alkenylation of $p$-xylene [16]. However, although the catalyst could be regenerated by calcination, further improvement in both catalytic activity and stability is required. On the whole, the Friedel-Crafts alkenylation reactions over solid acid catalysts have been scarcely reported, although this strategy could be a promising approach for the synthesis of 1,1-diarylalkenes with easy separation, green, and atom efficient features. Therefore, the development of novel, low-cost, and robust solid acid catalysts for Friedel-Crafts alkenylation is highly desirable, but still remains a challenge.

Based on our previously developed $\mathrm{SO}_{4}{ }^{2-} /$ meso- $\mathrm{La}_{0.1} \mathrm{Zr}_{0.9} \mathrm{O}_{\delta}$ solid acid catalyst, the tuning of the acidic sites and their accessibility was investigated by regulating the textural features and acidic properties of $\mathrm{SO}_{4}{ }^{2-} /$ meso-La0.1 $\mathrm{Zr}_{0.9} \mathrm{O}_{\delta}$ solid acids. Various characterization techniques including $\mathrm{N}_{2}$ physisorption, X-ray diffraction (XRD), $\mathrm{NH}_{3}$ temperature-programmed desorption ( $\mathrm{NH}_{3}$-TPD), and thermogravimetric analysis (TGA) were employed to explore the relationship between the nature of the catalyst and its catalytic performance in Friedel-Crafts alkenylation. It was found that the textural features and acidic properties of $\mathrm{SO}_{4}{ }^{2-} /$ meso-La0.1 $\mathrm{Zr}_{0.9} \mathrm{O}_{\delta}$ solid acids can be efficiently modulated by changing the preparation conditions of the meso-La0.1 $\mathrm{Zr}_{0.9} \mathrm{O}_{\delta}$ composite. As a consequence, the catalytic performance of the $\mathrm{SO}_{4}{ }^{2-} /$ meso- $\mathrm{La}_{0.1} \mathrm{Zr}_{0.9} \mathrm{O}_{\delta}$ solid acid catalyst in Friedel-Crafts alkenylation was significantly improved. Moreover, the developed $\mathrm{SO}_{4}{ }^{2-} /$ meso-La0.1 $\mathrm{Zr}_{0.9} \mathrm{O}_{\delta}$ catalyst demonstrated excellent catalytic performance in the alkenylation of diverse aromatics with phenylacetylene to their corresponding $\alpha$-arylstyrenes. In combination with the previously established complete regeneration of the used catalyst by a facile calcination treatment and the improved catalytic performance reported in this work, the optimized $\mathrm{SO}_{4}{ }^{2-} /$ meso-La0.1 $\mathrm{Zr}_{0.9} \mathrm{O}_{\delta}$ solid acid could be a potential catalyst for the alkenylation of diverse aromatics with phenylacetylene to their corresponding $\alpha$-arylstyrenes.

\section{Experimental}

\subsection{Catalyst preparation}

Mesoporous $\mathrm{La}_{0.1} \mathrm{Zr}_{0.9} \mathrm{O}_{\delta}$ composite oxides were synthesized by the previously reported surfactant-assisted hydrothermal crystallization method [16]. Typically, the zirconium nitrate (AR, Sinopharm Group, China) and lanthanum nitrate (AR, Tianjin Guangfu Institute, China) with a 9:1 molar ratio of $\mathrm{Zr}$ to La were dissolved in deionized water. A certain amount of CTAB (AR, Kermel, China) with various molar ratios of CTAB to metal ions $\left(N_{\mathrm{t} / \mathrm{m}}=0.10,0.13,0.15,0.18\right.$, and 0.20$)$ was dissolved in deionized water to give a clear homogeneous solution. The two solutions were then mixed under continuous stirring. Subsequently, various amounts of an ammonium solution $\left(N_{\mathrm{a} / \mathrm{m}}=14,16,18,20\right)$ were added dropwise into the mixture. After precipitation, the gelatinous pale mixture was 
stirred for another $4 \mathrm{~h}$ followed by a hydrothermal crystallization process at various hydrothermal temperatures $\left(T_{\text {hydro }}=75\right.$, 90,105 , and $120^{\circ} \mathrm{C}$ ) for different hydrothermal time (thydro $=$ 36,60 , and $84 \mathrm{~h}$ ) in a sealed Teflon autoclave. The solid product was filtered, washed, dried, and then calcined in a muffle furnace at $550{ }^{\circ} \mathrm{C}$ for $6 \mathrm{~h}$ to obtain a series of mesoporous $\mathrm{La}_{0.1} \mathrm{Zr}_{0.9} \mathrm{O}_{\delta}$ composite oxides. The various $\mathrm{SO}_{4}{ }^{2-} / \mathrm{meso}$ $\mathrm{La}_{0.1} \mathrm{Zr}_{0.9} \mathrm{O}_{\delta}$ solid acid catalyst samples with different $N_{\mathrm{t} / \mathrm{m}}, N_{\mathrm{a} / \mathrm{m}}$, $T$ hydro, and thydro were prepared by the impregnation method with $\mathrm{H}_{2} \mathrm{SO}_{4}(1 \mathrm{~mol} / \mathrm{L})$ as impregnant and a subsequent drying and calcination process.

\subsection{Catalyst characterization}

Nitrogen physisorption experiments were performed at $-196{ }^{\circ} \mathrm{C}$ on a BeiShiDe 3H-2000PS1 surface area porosity analyzer. The specific surface area was calculated by the BET method and the pore size distribution was calculated by the Barrett-Joyner-Halenda (BJH) model from the desorption branch of the isotherms. The coke amount deposited on the spent catalysts was obtained by TGA analysis using a PerkinElmer STA 6000 with a heating rate of $10{ }^{\circ} \mathrm{C} \mathrm{min}-1$ from 30 to $800{ }^{\circ} \mathrm{C}$ in an air stream. XRD patterns of the samples were recorded from $0^{\circ}$ to $10^{\circ}$ and $10^{\circ}$ to $80^{\circ}$ with a step width of $0.02^{\circ}$ using a Rigaku D/max-2400 apparatus using $\mathrm{Cu} K_{\alpha}$ radiation.

$\mathrm{NH}_{3}$-TPD measurements were performed to characterize the acidic properties of the samples. After pre-treatment of 50 mg samples in $\mathrm{Ar}$ (heating to $450{ }^{\circ} \mathrm{C}$ with a ramp rate of 10 ${ }^{\circ} \mathrm{C} / \mathrm{min}$, then kept at $450{ }^{\circ} \mathrm{C}$ for $0.5 \mathrm{~h}$ under an Ar flow of 30 $\mathrm{mL} / \mathrm{min})$, the samples were saturated with ammonia $(10 \%$ $\mathrm{NH}_{3}-90 \% \mathrm{Ar}$ ) at $100{ }^{\circ} \mathrm{C}$ using the pulse injection method. Finally, the $\mathrm{NH}_{3}$ desorption step was performed from 100 to $850{ }^{\circ} \mathrm{C}$ at a ramp rate of $10{ }^{\circ} \mathrm{C} / \mathrm{min}$ under an Ar flow of $30 \mathrm{~mL} / \mathrm{min}$. The $\mathrm{NH}_{3}$-TPD profiles were obtained by monitoring the desorbed ammonia with a thermal conductivity detector.

The XPS experiments of the fresh and spent solid acid catalysts were performed on an ESCALAB 250 XPS system with a monochromatized Al $K_{\alpha}$ X-ray source $(15 \mathrm{kV}, 150 \mathrm{~W}, 500 \mu \mathrm{m}$, pass energy $=50 \mathrm{eV}$ ). The binding energy was calibrated according to the $\mathrm{C} 1 s$ photoelectron peak at $284.6 \mathrm{eV}$, and the binding energy of S $2 p$ was analyzed at $152-175 \mathrm{eV}$, using the Shirley baseline-correction method.

The type of acid sites (Brönsted (B) and Lewis (L)) and relative amount (B/L) were measured by Py-IR. The Py-IR spectra were recorded at room temperature in the wavenumber range of 1590-1410 $\mathrm{cm}^{-1}$ on an EQUINOX-55 Fourier transform infrared spectrometer (BRUKER). The as-prepared solid acid catalysts were pressed into a self-supporting wafer (ca. 15 $\mathrm{mg} / \mathrm{cm}$ ), and introduced into a quartz IR cell with $\mathrm{CaF}_{2}$ windows. The samples were pretreated in situ by heating in a stream of helium at $30 \mathrm{~mL} / \mathrm{min}$ from room temperature to 450 ${ }^{\circ} \mathrm{C}$ and $5 \times 10^{-3}$ Pa for $30 \mathrm{~min}$. The cell was subsequently cooled to room temperature and pyridine vapor was passed into the cell and adsorbed onto the optimized (in this work) and the unoptimized (previously developed) $\mathrm{SO}_{4}{ }^{2-} /$ meso- $\mathrm{La}_{0.1} \mathrm{Zr}_{0.9} \mathrm{O}_{\delta}$ solid acid catalysts for a period of $30 \mathrm{~min}$. After removal of the excess pyridine, the spectrum was recorded. The sample was then evacuated at 150 and $450{ }^{\circ} \mathrm{C}$ for $30 \mathrm{~min}$ and a corresponding spectrum was recorded to distinguish the acid site. The relative intensities of the vibration bands at 1540 and $1450 \mathrm{~cm}^{-1}$ were assigned to the B and L acid sites, respectively.

\subsection{Catalyst performance test}

The catalytic performance measurements for the alkenylation of $p$-xylene with phenylacetylene was performed in a stainless steel fixed-bed continuous-flow reactor. In total, $1.0 \mathrm{~g}$ of catalyst pressed into tablets and sieved into 20-60 mesh was loaded into the reactor for all the reaction tests, and the remaining space of the reactor tube was filled with 20-60 mesh quartz granules. Before the introduction of feedstock, the catalyst was pre-activated in situ for $1 \mathrm{~h}$ under a $\mathrm{N}_{2}$ flow at 30 $\mathrm{mL} / \mathrm{min}$. The liquid stream was introduced into the fixed-bed reactor by a syringe pump. $\mathrm{N}_{2}$ (99.999\% purity) was used to maintain system pressure. Quantitative analysis of the collected reaction mixture from the fixed-bed reactor was performed on a FULI 9790 II GC equipped with an HP-5 column (30 $\mathrm{m} \times 0.32$ $\mathrm{mm} \times 0.25 \mu \mathrm{m})$, and an FID detector. As an evaluation standard of the alkenylation reaction, the phenylacetylene conversion was calculated by mass percentage of the transformed phenylacetylene from the total amount of phenylacetylene introduced in the feed. Based on the GC-MS data and our previous work [13-16], besides the main product $\alpha$-arylstyrene (I), a series of byproducts such as acetophenone (II), $\beta$-(2,5-dimethylphenyl) styrene (III), $\alpha$-(2,5-dimethylphenyl) ethylbenzene (IV), and oligomers (V) were detected, indicating the alkenylation reaction of $p$-xylene with phenylacetylene is a quite complex competition process. Besides the alkenylation, many side reactions, such as hydration of phenylacetylene, hydrogenation of $\alpha$-arylstyrene, thermodynamic control alkenylation, and the oligomerization reactions take place simultaneously. The scope of the substrates that can be used for the developed solid superacid catalyst-mediated alkenylation was investigated by employing a diverse range of aromatics as substrates.

\section{Results and discussion}

\subsection{Effect of the molar ratio of template to metal ions}

Table 1 presents the results of alkenylation of $p$-xylene with

\section{Table 1}

Effect of the $N_{\mathrm{t} / \mathrm{m}}$ value on the catalytic performance of $\mathrm{SO}_{4}{ }^{2-} /$ meso- $\mathrm{La}_{0.1} \mathrm{Zr}_{0.9} \mathrm{O}_{\delta}$ solid acid catalysts for the alkenylation of $p$-xylene with phenylacetylene.

\begin{tabular}{lcccccc}
\hline \multirow{2}{*}{$N_{\mathrm{t} / \mathrm{m}}$} & Conv. & \multicolumn{5}{c}{ Product distribution (\%) } \\
\cline { 3 - 7 } & $(\%)$ & I & II & III & IV & V \\
\hline 0.10 & 80.2 & 93.5 & 0.1 & 5.0 & 0.1 & 1.3 \\
0.13 & 82.7 & 93.6 & 0.2 & 4.6 & 0.1 & 1.5 \\
0.15 & 85.1 & 93.1 & 0.2 & 4.0 & 0.1 & 2.6 \\
0.18 & 91.6 & 93.7 & 0.1 & 3.0 & 0.2 & 3.0 \\
0.20 & 91.7 & 92.3 & 0.2 & 4.6 & 0.1 & 2.8 \\
\hline
\end{tabular}

Reaction conditions: catalyst $1.0 \mathrm{~g}, n_{\mathrm{Ar} /} n_{\text {Phen }}=25, T_{\mathrm{r}}=150^{\circ} \mathrm{C}, P_{\mathrm{s}}=1.0$ $\mathrm{MPa}, \mathrm{VHSV}=6 \mathrm{~mL} /\left(\mathrm{g}_{\text {cat }} \cdot \mathrm{h}\right), \mathrm{TOS}=8 \mathrm{~h}$. 
phenylacetylene over the $\mathrm{SO}_{4}{ }^{2-} /$ meso- $\mathrm{La}_{0.1} \mathrm{Zr}_{0.9} \mathrm{O}_{\delta}$ solid acids prepared with various molar ratios of the template (CTAB) to the total metal ions containing $\mathrm{La}$ and $\mathrm{Zr}\left(N_{\mathrm{t}} / \mathrm{m}\right)$. For this preparation process, the 18 of $N_{\mathrm{a} / \mathrm{m}}, 105^{\circ} \mathrm{C}$ of $T_{\text {hydro, and }} 60 \mathrm{~h}$ of $t_{\text {hydro }}$ were used. It can be observed that the conversion of phenylacetylene increases with the increase of $N_{\mathrm{t}} / \mathrm{m}$ from 0.10 to 0.18 . As the $N_{\mathrm{t} / \mathrm{m}}$ increases further the conversion remains almost unchanged. $91.6 \%$ of phenylacetylene conversion with $93.1 \%$ of the selectivity towards the main product $\alpha$-(2,5-dimethylphenyl)-styrene can be obtained when $N_{\mathrm{t} / \mathrm{m}}$ is 0.18 . Furthermore, the $N_{\mathrm{t} / \mathrm{m}}$ increases up to 0.18 leads to an increase in oligomers but a decrease in isomer ( $\beta$-(2,5-dimethylphenyl) styrene). However, interestingly, the further increase of $N_{\mathrm{t} / \mathrm{m}}$ from 0.18 to 0.2 results in a decrease in oligomers but an increase in isomers. Considering the reaction results and the economic efficiency, the optimum $N_{\mathrm{t} / \mathrm{m}}$ is 0.18 .

Nitrogen physisorption, $\mathrm{NH}_{3}-\mathrm{TPD}$, and XRD experiments were performed to reveal the relationship between the nature of the catalyst and its catalytic performance. Fig. 1 presents the adsorption-desorption isotherms, pore size distributions (Fig. 1(a)), and $\mathrm{NH}_{3}$-TPD profiles (Fig. 1(b)) of the $\mathrm{SO}_{4}{ }^{2-} /$ mesoLa0.1 $\mathrm{Zr}_{0.9} \mathrm{O}_{\delta}$ solid acids prepared with various $N_{\mathrm{t} / \mathrm{m}}$ values. As shown in Fig. 1(a), the type IV isotherm with a hysteresis loop is a typical feature of mesoporous materials [35,36], indicating the existence of a mesoporous structure in the as-prepared solid superacids. From the inset in Fig. 1(a) and Table 2, the increase of $N_{\mathrm{t}} / \mathrm{m}$ from 0.15 to 0.18 leads to an increase in the surface area from 76 to $81 \mathrm{~m}^{2} / \mathrm{g}$ and to a slight decrease in the total pore volume ( $V_{\text {total }}$ ) from 0.36 to $0.35 \mathrm{~cm}^{3} / \mathrm{g}$, as well as an increase in the amount of mesopores. The further increase of $N_{\mathrm{t} / \mathrm{m}}$ from 0.18 to 0.20 leads to an increase in the surface area but to a decrease in the pore volume and a decrease in the amount of mesopores. The increase in mesopores with the increase of $N_{\mathrm{t} / \mathrm{m}}$ from 0.15 to 0.18 can enhance the diffusion of the formed main product $\alpha$-(2,5-dimethylphenyl)-styrene. As a result, the amount of thermodynamically stable side product $\beta$-(2,5-dimethylphenyl)-styrene formed by isomerization of the main product decreases owing to the decreased staying time as a result of quick diffusion. The decreased amount of mesopores and pore volume by the further increase of $N_{\mathrm{t} / \mathrm{m}}$ from 0.18 to
Table 2

Effect of $N_{\mathrm{t} / \mathrm{m}}$ value on the $C S_{\mathrm{zr}}$ and $V_{\text {total }}$ of the as-synthesized $\mathrm{SO}_{4}{ }^{2-} /$ meso- $\mathrm{La}_{0.1} \mathrm{Zr}_{0.9} \mathrm{O}_{2}$ solid acid catalyst.

\begin{tabular}{lcc}
\hline$N_{\mathrm{t} / \mathrm{m}}$ & $C S_{\mathrm{Zr}} \mathrm{a}(\mathrm{nm})$ & $V_{\text {total }} \mathrm{b}\left(\mathrm{cm}^{3} / \mathrm{g}\right)$ \\
\hline 0.15 & 6.1 & 0.36 \\
0.18 & 5.9 & 0.35 \\
0.20 & 5.8 & 0.34 \\
\hline
\end{tabular}

a Estimated by Scherrer equation from XRD patterns; ${ }^{b}$ From $\mathrm{N}_{2}$ physisorption.

0.20 leads to an increase in isomers owing to a worse diffusion of the main product. From Fig. 1(b), the $\mathrm{NH}_{3}$-TPD profiles can be divided into four regions (150-300, 300-450, 450-600, and above $600{ }^{\circ} \mathrm{C}$ ), which can be assigned as weak, medium, strong, and super acidic sites, respectively. The acidic properties of the sulfated metal oxides are dependent on the textural features and the crystalline phase, besides the component of the oxides [19-34]. The increase of the surface area as $N_{\mathrm{t} / \mathrm{m}}$ is increased from 0.15 to 0.18 leads to an increase in the amount of acidic sites, which results in the increased conversion shown in Table 1. No obvious change in weak and medium acidic sites can be observed as the $N_{\mathrm{t}} / \mathrm{m}$ is increased further from 0.18 to 0.20 , whereas there is an obvious decrease in strong acidic sites. From the reaction results in Table 1, the two samples with $N_{\mathrm{t} / \mathrm{m}}$ of 0.18 and 0.20 demonstrate similar catalytic activity, suggesting that the weak and medium acidic sites are the active sites for alkenylation.

From Fig. 2, the peaks in the XRD patterns of the three samples at $30.1^{\circ}, 34.7^{\circ}, 50.1^{\circ}, 59.5^{\circ}$, and $73.7^{\circ}$ can be well-resolved, indexed as the (011), (110), (112), (121), and (123) planes of tetragonal phase of $\mathrm{ZrO}_{2}$, respectively [35,37-39]. No diffraction peaks corresponding to $\mathrm{La}_{2} \mathrm{O}_{3}$ phase or to $m-\mathrm{ZrO}_{2}$ can be observed, which is ascribed to the insertion of La into the $\mathrm{ZrO}_{2}$ lattice and the led stabilization effect on $t-\mathrm{ZrO}_{2}$ phase $[16,35]$. The increase in CTAB concentration results in a decrease in the average crystallite size $\left(C S_{\mathrm{Zr}}\right)$ shown in Table 2 owing to the inhibiting effect of surface micelles on the agglomeration of $\mathrm{ZrO}_{2}$ particles [40]. The interaction between $\mathrm{SO}_{4}{ }^{2-}$ and $\mathrm{ZrO}_{2}$ would be strengthened as the average crystallite size decreases. As a result, the peak towards the super acid centered at above $600{ }^{\circ} \mathrm{C}$ can be seen on the $\mathrm{SO}_{4}{ }^{2-} /$ meso- $\mathrm{La}_{0.1} \mathrm{Zr}_{0.9} \mathrm{O}_{\delta}$ solid

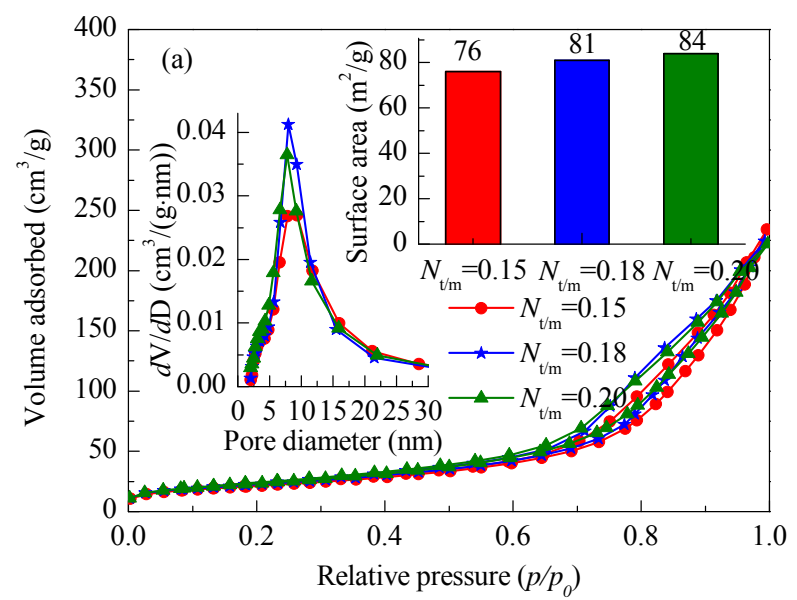

Fig. 1. $\mathrm{N}_{2}$ adsorption-desorption isotherms (a) and $\mathrm{NH}_{3}$-TPD profiles (b) of the as-prepared $\mathrm{SO}_{4}^{2-} /$ meso-La0.1 $\mathrm{Zr}_{0.9} \mathrm{O}_{\delta}$ solid acid catalysts with various $N_{\mathrm{t} / \mathrm{m}}$ values. Insets in Fig. 1(a) are the specific surface area and BJH pore diameter distribution from the desorption branch. 


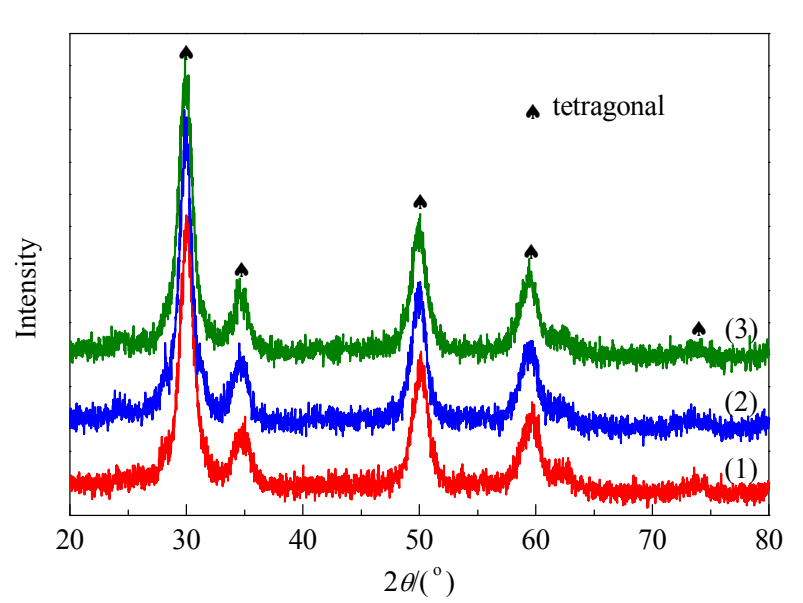

Fig. 2. XRD patterns of the $\mathrm{SO}_{4}{ }^{2-} /$ meso-La0. $\mathrm{Zr}_{0.9} \mathrm{O}_{2}$ solid acid catalysts with various $N_{\mathrm{t} / \mathrm{m}}$ values. (1) $N_{\mathrm{t} / \mathrm{m}}=0.15$; (2) $N_{\mathrm{t} / \mathrm{m}}=0.18$; (3) $N_{\mathrm{t} / \mathrm{m}}=0.20$.

acids with 0.18 and 0.20 of $N_{\mathrm{t} / \mathrm{m}}$, but a visible peak can be seen towards super acid on the $\mathrm{SO}_{4}{ }^{2-} /$ meso-La0.1 $\mathrm{Zr}_{0.9} \mathrm{O}_{\delta}$ solid acid with 0.15 of $N_{\mathrm{t} / \mathrm{m}}$. The $\mathrm{SO}_{4}{ }^{2-} /$ meso-La0.1 $\mathrm{Zr}_{0.9} \mathrm{O}_{\delta}$ solid acid with 0.18 of $N_{\mathrm{t} / \mathrm{m}}$ has similar strong acidic sites to that with 0.15 of $N_{\mathrm{t} / \mathrm{m}}$, but the former has super acidic sites. As a result, more oligomers were observed on the former (Table 1). Although there are more super acidic sites on $\mathrm{SO}_{4}{ }^{2-} /$ meso-La0.1Zro.9O $\delta$ solid acid with of $0.20 \mathrm{~N}_{\mathrm{t} / \mathrm{m}}$ than the one with 0.18 of $N_{\mathrm{t} / \mathrm{m}}$, much less strong acidic sites can be observed on the former. As shown in Table 1, less oligomers were observed on the former. Correlating the oligomerization results to acidic properties, it can be proposed that the strong and super acidic sites are the main active sites for oligomerization.

From the above analysis, it can be concluded that the catalytic performance including activity and product distribution is significantly dependent on the acidic properties and pore structure of the solid acid catalysts. The acidic properties are affected by textural features and crystal phase of the meso-La0.1 $\mathrm{Zr}_{0.90} \mathrm{O}_{\delta}$ composite oxides. The $\mathrm{N}_{\mathrm{t} / \mathrm{m}}$ value has an influence on the textural nature, acidic sites, and crystalline phase of the catalyst. The increase in weak and medium acidic sites is of benefit for the alkenylation reaction, but strong and super acidic sites would lead to oligomerization and deep polymerization. Therefore, the 0.18 of $N_{\mathrm{t} / \mathrm{m}}$ is ideal for obtaining solid acid catalysts with excellent alkenylation properties.

\subsection{Effect of molar ratio of ammonia to metal ions}

The ammonia concentration would affect the formation of surfactant micelles, the nucleation and growth of $\mathrm{Zr}(\mathrm{OH})_{4}$, as well as the assembly process for mesoporous $\mathrm{Zr}-\mathrm{O}$ sol and gel. As a consequence, the tuning of the $N_{\mathrm{a} / \mathrm{m}}$ values by fixing the other parameters $\left(N_{\mathrm{t} / \mathrm{m}}=0.18, T_{\text {hydro }}=105^{\circ} \mathrm{C}\right.$, and $\left.t_{\text {hydro }}=60 \mathrm{~h}\right)$ may efficiently regulate the textural features and the $\mathrm{ZrO}_{2}$ crystal of the meso-La $\mathrm{Lar}_{0.9} \mathrm{O}_{\delta}$ composite oxides, which in turn affects the catalytic performance. The catalytic performance of the $\mathrm{SO}_{4}^{2-} /$ meso-La0.1 $\mathrm{Zr}_{0.9} \mathrm{O}_{\delta}$ solid acids prepared with various $N_{\mathrm{a} / \mathrm{m}}$ values for the alkenylation of $p$-xylene with phenylacetylene was investigated. From the results presented in Table 3,
Table 3

Effect of the $N_{\mathrm{a} / \mathrm{m}}$ value on the catalytic performance of $\mathrm{SO}_{4}^{2-} / \mathrm{meso}^{2} \mathrm{La}_{0.1} \mathrm{Zr}_{0.9} \mathrm{O}_{\delta}$ solid acid catalysts for the alkenylation of $p$-xylene with phenylacetylene.

\begin{tabular}{lcccccc}
\hline \multirow{2}{*}{$N_{\mathrm{a} / \mathrm{m}}$} & Con. & \multicolumn{5}{c}{ Production distribution (\%) } \\
\cline { 3 - 7 } & $(\%)$ & I & II & III & IV & V \\
\hline 14 & 83.7 & 92.1 & 0.3 & 4.0 & 0.1 & 3.5 \\
16 & 91.8 & 93.9 & 0.3 & 2.5 & 0.2 & 3.2 \\
18 & 91.6 & 93.7 & 0.1 & 3.0 & 0.2 & 3.0 \\
20 & 84.4 & 93.3 & 0.2 & 3.9 & 0.1 & 2.5 \\
\hline
\end{tabular}

Reaction conditions: catalyst $1.0 \mathrm{~g}, n_{\mathrm{Ar} /} n_{\mathrm{Phen}}=25, T_{\mathrm{r}}=150{ }^{\circ} \mathrm{C}, P_{\mathrm{s}}=1.0$ $\mathrm{MPa}, \mathrm{VHSV}=6 \mathrm{~mL} /\left(\mathrm{g}_{\mathrm{cat}} \cdot \mathrm{h}\right), \mathrm{TOS}=8 \mathrm{~h}$.

the conversion increases with the increase of $N_{\mathrm{a}} / \mathrm{m}$ from 14 to 16. No visible change takes place as $N_{\mathrm{a} / \mathrm{m}}$ is increased from 16 to 18 . However, further increase of $N_{\mathrm{a} / \mathrm{m}}$ from 18 to 20 leads to an obvious decrease in catalytic activity. The opposite odder towards isomers can be observed. Moreover, a monotonous decrease in oligomer percentage with the increase of $N_{\mathrm{a} / \mathrm{m}}$ from 14 to 20 can be seen. From the results, the 16 of $N_{\mathrm{a} / \mathrm{m}}$ is optimal.

$\mathrm{N}_{2}$ physisorption, $\mathrm{NH}_{3}-\mathrm{TPD}$, and XRD were employed to investigate the structure-performance relationships of the catalysts. $\mathrm{N}_{2}$ adsorption-desorption isotherms and the corresponding BJH pore size distributions using the desorption branch of the isotherm, as well as $\mathrm{NH}_{3}$-TPD profiles of $\mathrm{SO}_{4}{ }^{2-} /$ meso-La0.1 $\mathrm{Zr}_{0.9} \mathrm{O}_{\delta}$ with various $\mathrm{Na} / \mathrm{m}$ values are shown in Fig. 3. The type IV isotherms with a hysteresis loop at a high relative pressure indicates that the $\mathrm{SO}_{4}{ }^{2-} /$ meso- $\mathrm{La}_{0.1} \mathrm{Zr}_{0.9} \mathrm{O}_{\delta}$ solid acid catalysts belong to the mesoporous material family [41]. From Fig. 3(a) and Table 4, the increase in the $N_{\mathrm{a} / \mathrm{m}}$ value from 14 to 16 leads to an increase in pore volume and the amount of larger mesopores, but it does not result in an increase in surface area. From the average crystallite size listed in Table 4, the increased $N_{\mathrm{a} / \mathrm{m}}$ value can lead to larger $\mathrm{ZrO}_{2}$ crystals. The increased pore volume and amount of larger mesopores of the $\mathrm{SO}_{4}^{2-} /$ meso- $\mathrm{La}_{0.1} \mathrm{Zr}_{0.9} \mathrm{O}_{\delta}$ prepared with the 16 of $N_{\mathrm{a} / \mathrm{m}}$ allow it to have more weak and medium acidic sites than those with 14 of $N_{\mathrm{a} / \mathrm{m}}$, which favors the alkenylation reaction. The increased pore volume and amount of larger mesopores also strengthens the diffusion of the main product, which suppresses the formation of the isomers. From the results in section 3.1, the oligomer percentage is strongly dependent on the strong and super acidic sites. Herein, the solid acid with 16 of $N_{\mathrm{a} / \mathrm{m}}$ produces less oligomers than the one with 14 of $\mathrm{Na}_{\mathrm{a} / \mathrm{m}}$, although the former has more strong and super acidic sites. This may be ascribed to the existence of larger mesopores on the former. The further increase of the $N_{\mathrm{a} / \mathrm{m}}$ from 16 to 20 leads to a decrease in the surface area and pore volume. This leads to a decrease in weak and medium acidic sites, which subsequently results in the lowering of the catalytic activity (Table 3). Although the peak centered at $549^{\circ} \mathrm{C}$ for the solid acid with 20 of $N_{\mathrm{a} / \mathrm{m}}$ is slightly higher than that of the one with 16 of $N_{\mathrm{a} / \mathrm{m}}$, the former has a lower number of strong acidic sites. Moreover, the larger crystallite size of $\mathrm{ZrO}_{2}$ for the solid acid with 20 of $N_{\mathrm{a} / \mathrm{m}}$ is higher than that for the solid acid with 16 of $N \mathrm{a} / \mathrm{m}$. The larger $\mathrm{ZrO}_{2}$ crystal size of the sample with 20 of $N \mathrm{a} / \mathrm{m}$ suppresses the interaction of $\mathrm{SO}_{4}{ }^{2-}$ and $\mathrm{ZrO}_{2}$. As a result, no super acidic sites 

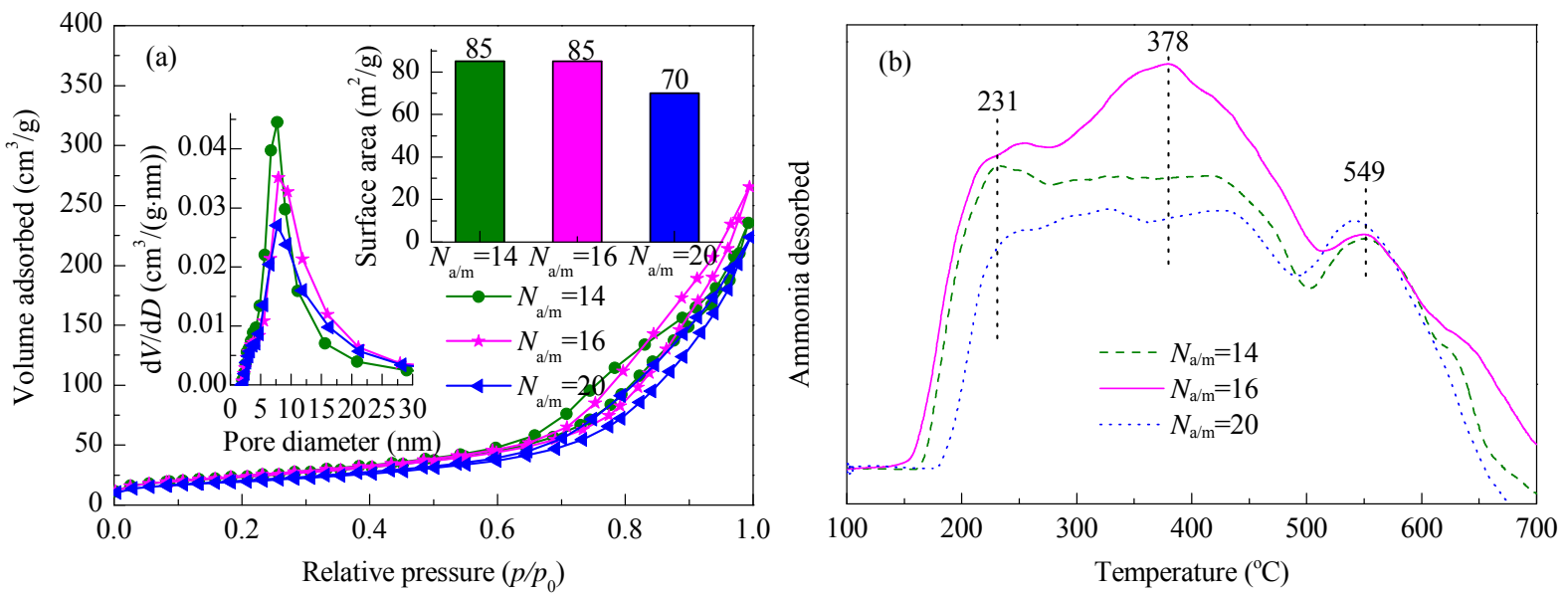

Fig. 3. $\mathrm{N}_{2}$ adsorption-desorption isotherms (a) and $\mathrm{NH}_{3}$-TPD profiles (b) of the as-prepared $\mathrm{SO}_{4}{ }^{2-} /$ meso- $\mathrm{La}_{0.1} \mathrm{Zr}_{0.9} \mathrm{O}_{\delta}$ solid acid catalysts with various molar ratios of ammonia to metal $\left(N_{\mathrm{a} / \mathrm{m}}\right)$. Insets in Fig. 3(a) are the specific surface area and BJH pore diameter distribution from the desorption branch.

on this sample can be observed. The lower amount of strong acidic sites and the absence of super acidic sites results in less oligomers. Furthermore, the decrease in mesopores of the sample with 20 of $N$ a/m in comparison with the one with 16 of $N_{\mathrm{a} / \mathrm{m}}$ leads to worse diffusion of the formed main product, which is of benefit for the formation of thermodynamically stable isomers. As a result, a higher isomer percentage can be observed for the catalyst prepared using 20 of $N_{\mathrm{a} / \mathrm{m}}$ compared with 16 of $N_{\mathrm{a} / \mathrm{m}}$, as shown in Table 3. The presence of more weak and medium acidic sites, larger pore volume, and larger mesopores make the solid acid catalyst exhibit excellent catalytic performance. Based on the established template and ammonia dosage, the effect of the hydrothermal conditions including the $T_{\text {hydro }}$ and $t_{\text {hydro }}$ on the nature of the catalyst and its catalytic performance in the alkenylation reaction was investigated.

\subsection{Effect of hydrothermal temperature}

Table 5 presents the effect of $T_{\text {hydro }}$ on the catalytic performance of the as-synthesized solid acid catalysts in the alkenylation of $p$-xylene with phenylacetylene by fixing the other conditions including the 0.18 of $N_{\mathrm{t} / \mathrm{m}}, 16$ of $N_{\mathrm{a} / \mathrm{m}}$, and $60 \mathrm{~h}$ of $t_{\text {hydro. }}$ As shown in Table 5, the conversion increases with the increase of Thydro up to $90{ }^{\circ} \mathrm{C}$, at which the conversion reaches a maximum (93.5\%). Further increase of $T_{\text {hydro }}$ leads to a decrease in conversion. A lower isomer percentage can be observed as $T_{\text {hydro }}$ is increased from 75 to $105^{\circ} \mathrm{C}$, however the isomer percentage rises as $T_{\text {hydro }}$ is further increased to $120^{\circ} \mathrm{C}$. Moreover, the oligomer percentage monotonously rises as the $T_{\text {hydro }}$ is increased

Table 4

Effect of $N_{\mathrm{a} / \mathrm{m}}$ value on the $C S_{\mathrm{zr}}$ and $V_{\text {total }}$ of the as-synthesized $\mathrm{SO}_{4}{ }^{2-} /$ meso- $\mathrm{La}_{0.1} \mathrm{Zr}_{0.9} \mathrm{O}_{2}$ solid acid catalyst.

\begin{tabular}{lcc}
\hline$N_{\mathrm{a} / \mathrm{m}}$ & $C S_{\mathrm{Zr}}^{\mathrm{a}}(\mathrm{nm})$ & $V_{\text {total }} \mathrm{b}\left(\mathrm{cm}^{3} / \mathrm{g}\right)$ \\
\hline 14 & 5.3 & 0.36 \\
16 & 5.5 & 0.41 \\
20 & 6.0 & 0.35 \\
\hline
\end{tabular}

a Estimated by Scherrer equation from XRD patterns; ${ }^{b}$ From $\mathrm{N}_{2}$ physisorption. in the whole investigated range.

From Fig. 4 and Table 6, an increase in the surface area from 57 to $79 \mathrm{~m}^{2} / \mathrm{g}$ and an enlarged pore volume from 0.28 to 0.37

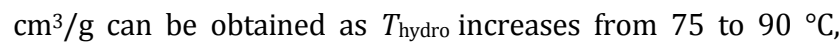
which leads to an increase in acidic sites. It is estimated by the Scherrer equation based on XRD patterns that the average crystal size decreases from 6.9 to $5.5 \mathrm{~nm}$ as Thydro increases from 75 to $90{ }^{\circ} \mathrm{C}$. The smaller $\mathrm{ZrO}_{2}$ crystallite size may allow stronger interaction between the $\mathrm{SO}_{4}{ }^{2-}$ and $\mathrm{Zr}$, which leads to the formation of super acidic sites. Besides the improved accessibility of the acidic sites by the increased surface area and pore volume, the increase in acidic sites is of benefit for the alkenylation reaction. As a result, the solid acid with the $90{ }^{\circ} \mathrm{C}$ of $T_{\text {hydro }}$ exhibits higher activity, as shown in Table 5 . The super acidic sites on the catalyst with the $90{ }^{\circ} \mathrm{C}$ of $T_{\text {hydro }}$ promote oligomerization, leading to the formation of more oligomers. The solid acid with the $90^{\circ} \mathrm{C}$ of $T_{\text {hydro }}$ has a larger pore volume than the

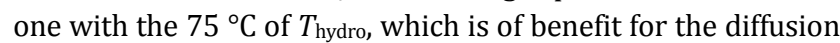
of the formed $\alpha$-arylstyrene. This reduces the chance of its isomerization. As a result, a decreased amount of the $\beta$-arylstyrene isomer can be obtained. Further increase of $T_{\text {hydro }}$ up to $120{ }^{\circ} \mathrm{C}$ leads to a decrease in surface area and pore volume, which results in a decrease in the active sites, the weak and medium acidic sites, for alkenylation. As a consequence, the conversion decreases from $91.8 \%$ to $84.1 \%$, as shown in Table 5. Moreover, the further decreased $\mathrm{ZrO}_{2}$ crystal size leads to more super acidic sites, as shown in Fig. 4(b). It was also ob-

\section{Table 5}

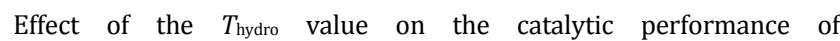
$\mathrm{SO}_{4}{ }^{2-} /$ meso- $\mathrm{La}_{0.1} \mathrm{Zr}_{0.9} \mathrm{O}_{\delta}$ solid acid catalysts for the alkenylation of $p$-xylene with phenylacetylene.

\begin{tabular}{lcccccc}
\hline \multirow{2}{*}{$\begin{array}{l}\text { hydro } \\
\left({ }^{\circ} \mathrm{C}\right)\end{array}$} & Conv. & \multicolumn{5}{c}{ Product distribution (\%) } \\
\cline { 4 - 7 } & $(\%)$ & I & II & III & IV & V \\
\hline 75 & 80.2 & 92.5 & 0.1 & 5.0 & 0.1 & 2.2 \\
90 & 93.5 & 93.8 & 0.3 & 3.4 & 0.1 & 2.4 \\
105 & 91.8 & 93.9 & 0.3 & 2.5 & 0.2 & 3.2 \\
120 & 84.1 & 93.1 & 0.4 & 3.7 & 0.2 & 3.5 \\
\hline
\end{tabular}

Reaction conditions: catalyst $1.0 \mathrm{~g}, n_{\mathrm{Ar} /} n_{\text {Phen }}=25, T_{\mathrm{r}}=150{ }^{\circ} \mathrm{C}, P_{\mathrm{s}}=1.0$ $\mathrm{MPa}, \mathrm{VHSV}=6 \mathrm{~mL} /\left(\mathrm{g}_{\mathrm{cat}} \cdot \mathrm{h}\right), \mathrm{TOS}=8 \mathrm{~h}$. 

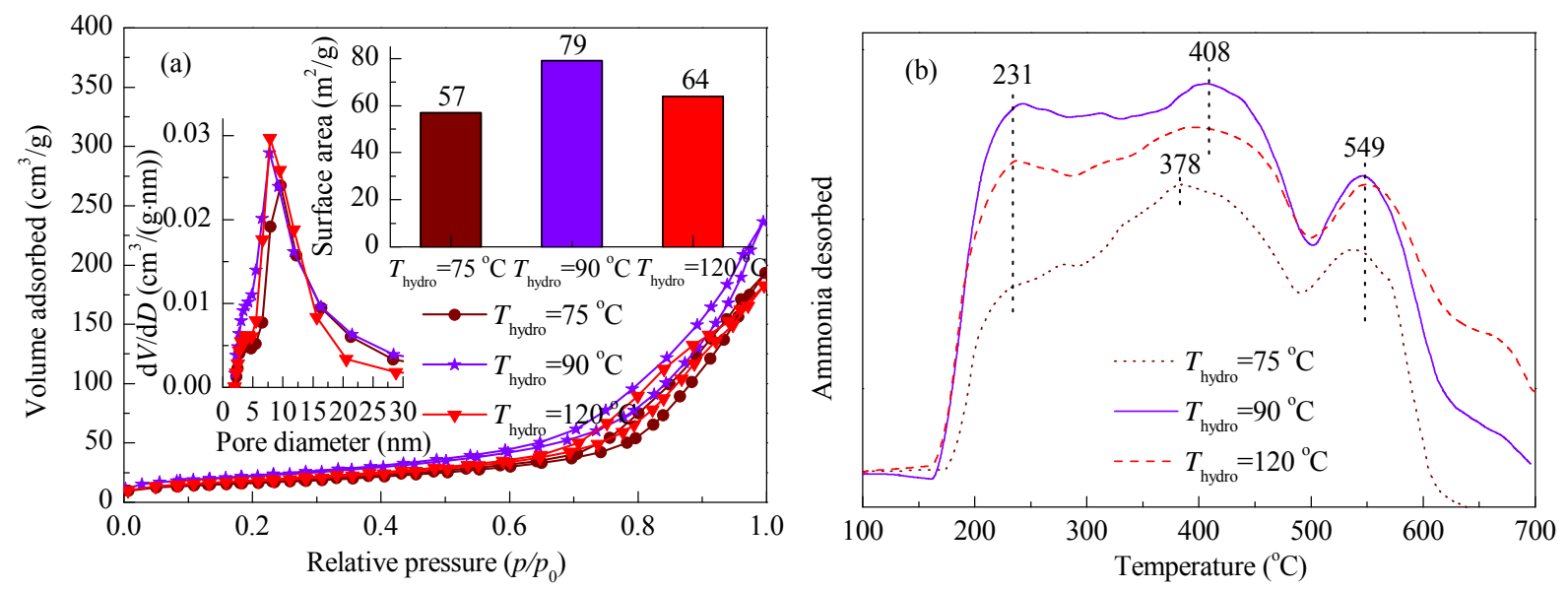

Fig. 4. $\mathrm{N}_{2}$ adsorption-desorption isotherms (a) and $\mathrm{NH}_{3}-\mathrm{TPD}$ profiles (b) of the as-prepared $\mathrm{SO}_{4}{ }^{2-} /$ meso- $\mathrm{La}_{0.1} \mathrm{Zr}_{0.9} \mathrm{O}_{\delta}$ solid acid catalysts at various hydrothermal temperatures ( $T_{\text {hydro }}$ ). Insets in Fig. 4(a) are the specific surface area and BJH pore diameter distribution from the desorption branch.

served that the $m-\mathrm{ZrO}_{2}$ phase exists in the solid acid with the $120{ }^{\circ} \mathrm{C}$ of $T_{\text {hydro }}$ [37-39], which might affect the acidic properties. The formation of more strong and super acidic sites would promote the formation of more oligomers. The decrease in the amount of larger mesopores on the $\mathrm{SO}_{4}^{2-} /$ meso-La0.1 $\mathrm{Zr}_{0.90} \mathrm{O}_{\delta}$ prepared with the $120^{\circ} \mathrm{C}$ of $T_{\text {hydro }}$ in comparison with the one with the $90^{\circ} \mathrm{C}$ of $T_{\text {hydro }}$ leads to a decrease in the amount of isomers. The solid acid prepared with the $75^{\circ} \mathrm{C}$ of $T$ hydro produces the most isomers among the three samples, which is ascribed to the smallest pore volume and lowest surface area.

\subsection{Effect of hydrothermal time}

Herein, the effect of thydro value ( $t_{\text {hydro }}=36,60$, and $84 \mathrm{~h}$ ) on the nature of the catalyst and the catalytic performance in the alkenylation was further investigated by fixing the other conditions including the 0.18 of $N_{\mathrm{t}} / \mathrm{m}, 16$ of $N_{\mathrm{a} / \mathrm{m}}$, and $90^{\circ} \mathrm{C}$ of $T_{\text {hydro. }}$ From Table 7, the phenylacetylene conversion increases with the increase of $t_{\text {hydro, }}$ and as $t_{\text {hydro }}$ reaches $60 \mathrm{~h}$, the conversion reaches a maximum (93.5\%). Further increase of thydro leads to a decrease in conversion. Moreover, from the product distribution, the extended hydrothermal time leads to a decrease in the percentage of isomers, but the solid acid with the $60 \mathrm{~h}$ of thydro has slightly higher formation of oligomers. Various characterization experiments were performed to explore the structure-performance relationship.

From Fig. 5 and Table 8, the increase of thydro from 36 to $60 \mathrm{~h}$ leads to an increase in the surface area, pore volume, the amount of weak and medium acidic sites, and the amount of the larger mesopores, which enhances the alkenylation reaction. As a result, there is an increase in the conversion, as shown in

\section{Table 6}

Effect of $T_{\text {hydro }}$ value on the $C S_{\mathrm{zr}}$ and $V_{\text {total }}$ of the as-synthesized $\mathrm{SO}_{4}^{2-} /$ meso-La $0.1 \mathrm{Zr}_{0.9} \mathrm{O}_{2}$ solid acid catalyst.

\begin{tabular}{lcc}
\hline$T_{\text {hydro }}\left({ }^{\circ} \mathrm{C}\right)$ & $C S_{\text {zr }}{ }^{\mathrm{a}}(\mathrm{nm})$ & $V_{\text {total }}{ }^{\mathrm{b}}\left(\mathrm{cm}^{3} / \mathrm{g}\right)$ \\
\hline 75 & 6.9 & 0.28 \\
90 & 5.5 & 0.37 \\
120 & 5.2 & 0.30 \\
\hline
\end{tabular}

a Estimated by Scherrer equation from XRD patterns; b From $\mathrm{N}_{2}$ physisorption.
Table 7, and the percentage of oligomers increases slightly. The increased thydro leads to a relatively smaller $\mathrm{ZrO}_{2}$ crystal size, which possess super acidic sites owing to a strengthened interaction between $\mathrm{SO}_{4}{ }^{2-}$ and $\mathrm{ZrO}_{2}$. The further increase of $t_{\text {hydro }}$ from 60 to $84 \mathrm{~h}$ leads to a decrease in the surface area, resulting in a decrease in weak, medium, and strong acidic sites. As a result, a much lower conversion with slightly lower oligomers can be observed. Furthermore, the pore volume and the amount of larger mesopores monotonously rises as the $t_{\text {hydro }}$ is extended, which results in the monotonous decrease in isomers owing to the suppression of the isomerization of the formed $\alpha$-arylstyrene.

From above, it can be concluded that the $\mathrm{SO}_{4}{ }^{2-} /$ meso-La0.1 $\mathrm{Zr}_{0.9} \mathrm{O}_{\delta}$ with appropriate preparation conditions for meso-La0.1 $\mathrm{Zr}_{0.9} \mathrm{O}_{\delta}$ composite oxides exhibited excellent catalytic performance in the alkenylation reaction. Correlating of the reaction results to the nature of the catalyst, we found that the catalytic activity and product distribution are strongly dependent on the acidic properties and the accessibility of acidic sites, which depend on the preparation conditions of meso-La. $\mathrm{Zr}_{0.9} \mathrm{O}_{\delta}$ composite oxides. The developed $\mathrm{SO}_{4}^{2-} /$ meso-La0.1 $\mathrm{Zr}_{0.9} \mathrm{O}_{\delta}$ with the 0.18 of $N_{\mathrm{t} / \mathrm{m}}, 16$ of $N_{\mathrm{a} / \mathrm{m}}, 90^{\circ} \mathrm{C}$ of $T$ hydro, and $60 \mathrm{~h}$ of thydro exhibits great potential for production of $\alpha$-arylstyrene through Friedel-Crafts alkenylation.

\subsection{Catalytic stability}

The catalytic stability and the scope of the substrates over the developed solid acid catalyst were investigated. The cata-

Table 7

Effect of the $t_{\text {hydro }}$ value on the catalytic performance of $\mathrm{SO}_{4}{ }^{2-} /$ meso- $\mathrm{La}_{0.1} \mathrm{Zr}_{0.9} \mathrm{O}_{\delta}$ solid acid catalysts for the alkenylation of $p$-xylene with phenylacetylene.

\begin{tabular}{lcccccc}
\hline \multirow{2}{*}{$T_{\text {hydro }}(\mathrm{h})$} & Conv. & \multicolumn{5}{c}{ Product distribution (\%) } \\
\cline { 3 - 7 } & (\%) & I & II & III & IV & V \\
\hline 36 & 84.1 & 93.4 & 0.4 & 3.9 & 0.1 & 2.2 \\
60 & 93.5 & 93.8 & 0.3 & 3.4 & 0.1 & 2.4 \\
84 & 86.9 & 94.3 & 0.3 & 3.2 & 0.1 & 2.2 \\
\hline
\end{tabular}

Reaction conditions: catalyst $1.0 \mathrm{~g}, n_{\mathrm{Ar} /} n_{\text {Phen }}=25, T_{\mathrm{r}}=150{ }^{\circ} \mathrm{C}, P_{\mathrm{s}}=1.0$ $\mathrm{MPa}, \mathrm{VHSV}=6 \mathrm{~mL} /\left(\mathrm{g}_{\mathrm{cat}} \cdot \mathrm{h}\right), \mathrm{TOS}=8 \mathrm{~h}$. 

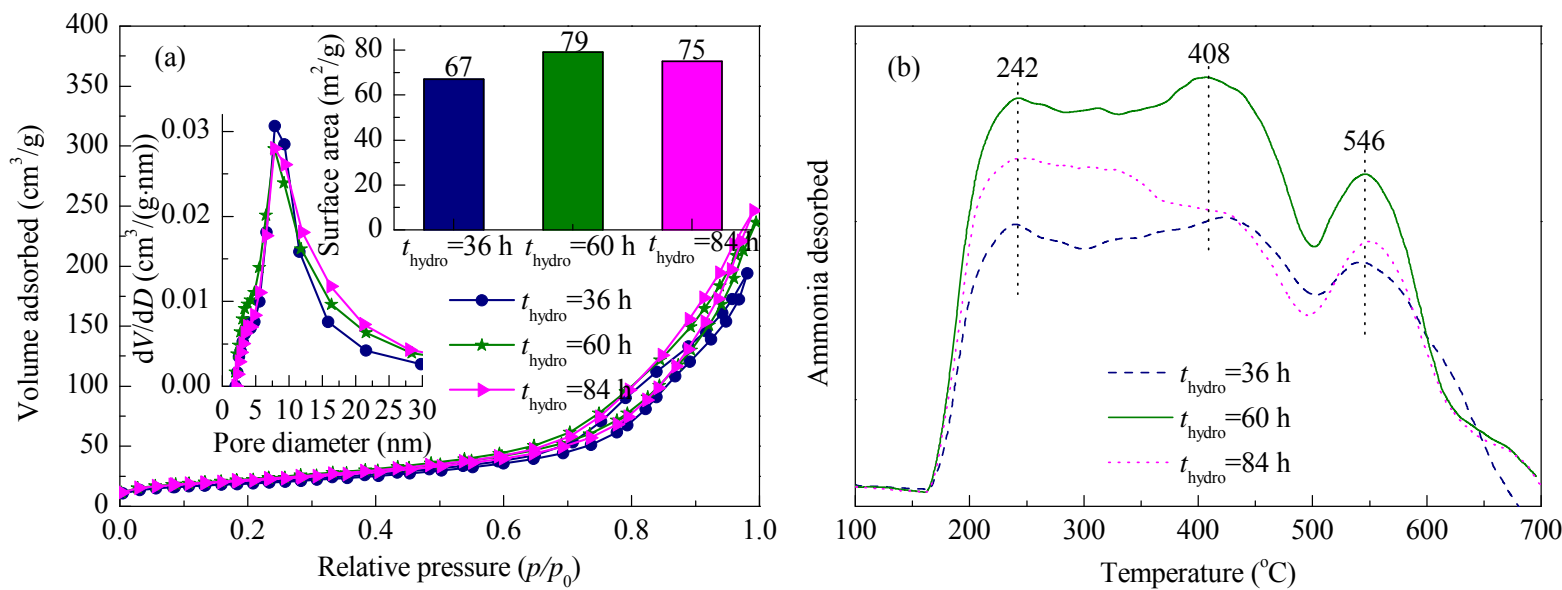

Fig. 5. $\mathrm{N}_{2}$ adsorption-desorption isotherms (a) and $\mathrm{NH}_{3}$-TPD profiles (b) of the as-prepared $\mathrm{SO}_{4}{ }^{2-} / \mathrm{meso}-\mathrm{La}_{0.1} \mathrm{Zr}_{0.9} \mathrm{O}_{\delta}$ solid acid catalysts with various hydrothermal times $\left(t_{\text {hydro }}\right)$. Insets in Fig. 5 a are the specific surface area and BJH pore diameter distribution from the desorption branch.

Table 8

Summary of the alkenylation of different aromatics with phenylacetylene over the developed $\mathrm{SO}_{4}{ }^{2-} /$ meso- $\mathrm{La}_{0.1} \mathrm{Zr}_{0.9} \mathrm{O}_{\delta}$ solid acid catalyst.

Entry Substrate

Reaction conditions: catalyst $1.0 \mathrm{~g}, n_{\mathrm{Ar}} n_{\mathrm{Phen}}=25, T_{\mathrm{r}}=150{ }^{\circ} \mathrm{C}, P_{\mathrm{s}}=1.0 \mathrm{MPa}, \mathrm{VHSV}=6 \mathrm{~mL} /\left(\mathrm{g}_{\mathrm{cat}} \cdot \mathrm{h}\right) ;{ }^{\mathrm{G} C \mathrm{GC}}$ yield; ${ }^{\mathrm{b}}$ The cyclohexane or dioxane was introduced into the feed for easy material transfer in the fixed-bed reactor.

lytic stability plays an important role in practical application of a solid acid catalyst. Therefore, the stability of the developed $\mathrm{SO}_{4}{ }^{2-} /$ meso- $\mathrm{La}_{0.1} \mathrm{Zr}_{0.9} \mathrm{O}_{2}$ solid acid in the alkenylation reaction of $p$-xylene with phenylacetylene was investigated. Fig. 6 presents the conversion and selectivity as a function of time on stream for the alkenylation over the optimized solid acid catalyst; the unoptimized catalyst (previously developed $\mathrm{SO}_{4}{ }^{2-} /$ meso-La0.1 $\mathrm{Zr}_{0.9} \mathrm{O}_{2}$ solid acid [16]) is included for comparison. From Fig. 6, the optimized $\mathrm{SO}_{4}^{2-} /$ meso- $\mathrm{La}_{0.1} \mathrm{Zr}_{0.9} \mathrm{O}_{\delta}$ in this work exhibits much higher stability in comparison with the unoptimized one, and more than $62.5 \%$ conversion can be maintained for up to $31 \mathrm{~h}$ of time on stream compared with only $45.4 \%$ conversion obtained for the unoptimized catalyst. From TGA experiments, the $15.1 \%$ and $25.6 \%$ of mass loss for the optimized and unoptimized solid acids, respectively, sug- gests a higher coke-resistant stability of the optimized catalyst. Therefore, the developed $\mathrm{SO}_{4}{ }^{2-} /$ meso-La $0.1 \mathrm{Zr}_{0.9} \mathrm{O}_{\delta}$ prepared under appropriate conditions could be a promising solid acid catalyst for the alkenylation reaction.

Py-IR is a powerful tool for investigating the acidic properties of the catalysts. The Py-IR spectra of the optimized solid catalyst in this work and the unoptimized solid acid catalysts at 150,300 , and $450{ }^{\circ} \mathrm{C}$ of desorption temperature, corresponding to total acidic sites, medium plus strong acidic sites, and strong acidic sites, respectively, were collected and are presented in Fig. 7. The optimized solid acid has more acidic sites, including $B$ and $L$ acids, in comparison with the unoptimized one. More interestingly, the remarkable increase in $\mathrm{L}$ acidic sites over the optimized solid acid catalyst can be seen in comparison with the increase in $\mathrm{B}$ acidic sites. The interaction of $\mathrm{SO}_{4}{ }^{2-}$ and $\mathrm{ZrO}_{2}$ 


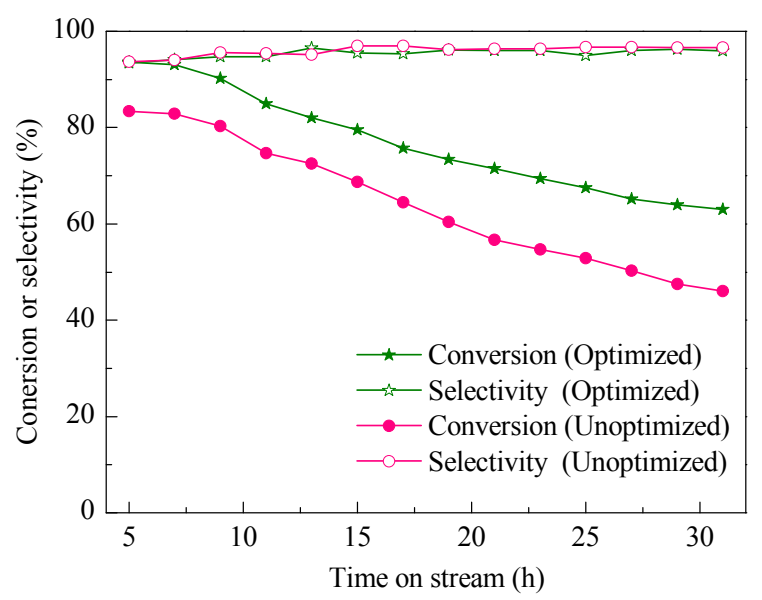

Fig. 6. The catalytic stability of the developed $\mathrm{SO}_{4}^{2-} /$ meso- $\mathrm{La}_{0.1} \mathrm{Zr}_{0.9} \mathrm{O}_{\delta}$ catalyst for the alkenylation of $p$-xylene with phenylacetylene. Reaction conditions: catalyst $1.0 \mathrm{~g}, n_{\mathrm{Ar}} / n_{\text {Phen }}=25, T_{\mathrm{r}}=150{ }^{\circ} \mathrm{C}, P_{\mathrm{s}}=1.0 \mathrm{MPa}, \mathrm{VHSV}=$ $6 \mathrm{~mL} /\left(\mathrm{g}_{\text {cat }} \cdot \mathrm{h}\right)$.

leads to the production of $\mathrm{L}$ acid sites, and subsequently the $\mathrm{B}$ acidic sites can be formed by the incorporation of $\mathrm{H}_{2} \mathrm{O}$ in the $\mathrm{L}$ acid sites. From references [13-16], both B and L acidic sites can enhance the alkenylation reaction, and therefore, the solid acid catalyst developed in this work exhibits a much higher catalytic activity for alkenylation in comparison with the unoptimized one. Moreover, the strong B acidic sites may enhance the polymerization side reactions. The notably increased amount of total acidic sites on the optimized catalyst dramatically increases the conversion of phenylacetylene in the main reaction, which decreases the concentration of phenylacetylene. This may weaken the polymerization and the subsequent coke deposition on the optimized catalyst. Furthermore, we investigated S-leaching in the reaction process by XPS analysis (S $2 p$ ) of the fresh and spent $\mathrm{SO}_{4}{ }^{2-} /$ meso-La0.1 $\mathrm{Zr}_{0.9} \mathrm{O}_{\delta}$. The XPS results demonstrate that the surface atomic ratio of $\mathrm{S}$ to $\mathrm{Zr}$ decreases from 0.24 to 0.20 after the catalyst is used in the above reaction process, implying that S-leaching is another reason for the decrease in conversion. More stable solid catalysts will be explored in the future.

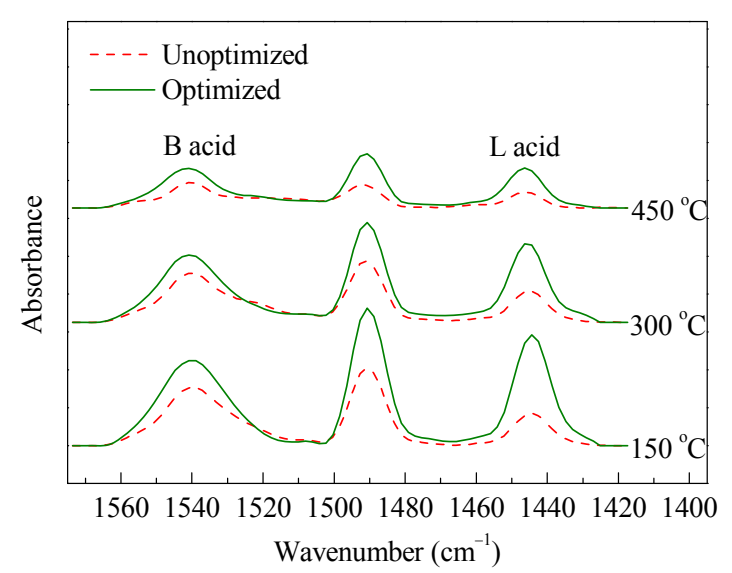

Fig. 7. Pyridine-IR spectra of the optimized and unoptimized $\mathrm{SO}_{4}{ }^{2-} /$ meso-La $\mathrm{La}_{0.1} \mathrm{Zr}_{0.9} \mathrm{O}_{\delta}$ solid acid catalysts.

\subsection{Scope of substrates}

Herein, the scope of the substrates for the alkenylation over the developed $\mathrm{SO}_{4}^{2-} /$ meso- $\mathrm{La}_{0.1} \mathrm{Zr}_{0.9} \mathrm{O}_{\delta}$ catalyst was investigated, and the reaction results are listed in Table 5. The developed solid acid catalyst demonstrates excellent catalytic performance with more than $90 \%$ conversion and high selectivity for the alkenylation of diverse aromatics, suggesting a broad scope of aromatics for the alkenylation for the production of different $\alpha$-arylstyrenes. Together with the facile regeneration of the used solid acid catalyst established in our previous paper [16], the developed $\mathrm{SO}_{4}{ }^{2-} /$ meso-La0.1 $\mathrm{Zr}_{0.9} \mathrm{O}_{\delta}$ could be considered as a potential candidate for clean and atom efficient production of diverse $\alpha$-arylstyrenes and industrially important intermediates through the Friedel-Crafts alkenylation of different aromatics with phenylacetylene.

\section{Conclusions}

The textural features and acidic properties of sulfated mesoporous lanthana-zirconia solid acid catalysts were efficiently tuned by adjusting the preparation conditions, including the molar ratio of the template to metal ions, molar ratio of ammonia to metal ions, hydrothermal temperature, and hydrothermal time, which significantly affected the acidic sites and their accessibility. As a consequence, the conversion and product distribution could be regulated. The optimized sulfated mesoporous lanthana-zirconia solid acid catalysts demonstrated much superior catalytic activity and stability and similar selectivity towards $\alpha$-arylstyrene to the unoptimized one. Combing the excellent catalytic activity, selectivity, and stability, as well as the broad scope of substrates and easy regeneration of the used catalyst, the developed sulfated mesoporous lanthana-zirconia solid acid catalysts could have great potential for industrial production of $\alpha$-arylstyrene through clean and atom efficient solid-acid-mediated Friedel-Crafts alkenylation of diverse aromatics with phenylacetylene.

\section{References}

[1] C. G. Jia, D. G. Piao, J. Oyamada, W. J. Lu, T. Kitamura, Y. Fujiwara, Science, 2000, 287, 1992-1995.

[2] K. Komeyama, R. Igawa, K. Takaki, Chem. Commun., 2010, 46, 1748-1750.

[3] R. S. Li, S. R. Wang, W. J. Lu, Org. Lett., 2007, 9, 2219-2222.

[4] M. Y. Yoon, J. H. Kim, D. S. Choi, U. S. Shin, J. Y. Lee, C. E. Song, Adv. Synth. Catal., 2007, 349, 1725-1737.

[5] C. E. Song, D. U. Jun, S. Y. Choung, E. J. Roh, S. G. Lee, Angew. Chem. Int. Ed., 2004, 43, 6183-6185.

[6] D. S. Choi, J. H. Kim, U. S. Shin, R. R. Deshmukh, C. E. Song, Chem. Commun., 2007, 3482-3484.

[7] T. Tsuchimoto, T. Maeda, E. Shirakawa, Y. Kawakami, Chem. Commun., 2000, 1573-1574.

[8] S. A. Aristov, A. V. Vasil'ev, G. K. Fukin, A. P. Rudenko, Russ. J. Org. Chem., 2007, 43, 691-705.

[9] Z. K. Zhao, W. H. Qiao, G. R. Wang, Z. S. Li, L. B. Cheng, J. Mol. Catal. A, 2006, 250, 50-56.

[10] N. Lucas, A. Bordoloi, A. P. Amrute, P. Kasinathan, A. Vinu, W. 


\title{
Graphical Abstract
}

Chin. J. Catal., 2016, 37: 1303-1313 doi: 10.1016/S1872-2067(15)61118-4

Tuning of the textural features and acidic properties of sulfated mesoporous lanthana-zirconia solid acid catalysts for alkenylation of diverse aromatics to their corresponding $\alpha$-arylstyrenes

Zhongkui Zhao*, Jinfeng Ran, Yongle Guo, Boyuan Miao, Guiru Wang Dalian University of Technology

Tuning of the textural features and acidic properties of sulfated mesoporous lanthana-zirconia solid acidsresults in potential catalyst for the industrial production of $\alpha$-arylstyrenes through clean and atom efficient alkenylation of diverse aromatics with phenylacetylene.

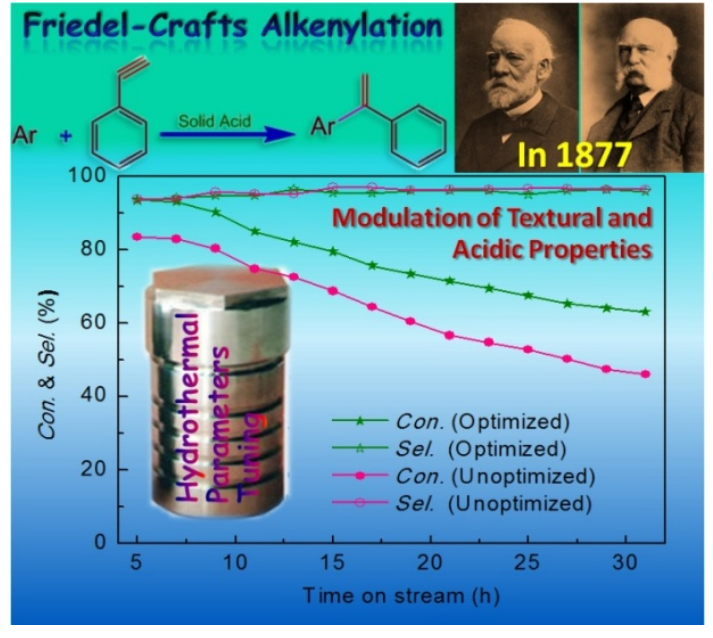

Bohringer, J. C. Q. Fletcher, S. B. Halligudi, Appl. Catal. A, 2010, 352 74-80.

[11] G. Kostrab, M. Lovic, I. Janotka, M. Bajus, D. Mravec, Appl. Catal. A, 2008, 335, 74-81.

[12] A. O. Shchukin, A. V. Vasilyev, Appl. Catal. A, 2008, 336, 140-147.

[13] Z. K. Zhao, Y. T. Dai, T. Bao, R. Z. Li, G. R. Wang, J. Catal., 2012, 288, 44-53.

[14] Z. K. Zhao, R. H. Jin, X. L. Lin, G. R. Wang, Energy Sources Part A, 2013, 35, 1761-1769.

[15] Z. K. Zhao, X. H. Wang, Appl. Catal. A, 2015, 503, 103-110.

[16] Z. K. Zhao, J. F. Ran, Appl. Catal. A, 2015, 503, 77-83.

[17] G. Sartori, F. Bigi, A. Pastorio, C. Porta, A. Arienti, R. Maggi, N. Moretti, G. Gnappi, Tetrahedron Lett., 1995, 36, 9177-9180.

[18] K. Y. Koltunov, S. Walspurger, J. Sommer, Chem. Commun., 2004, 1754-1755

[19] A. K. Shah, M. Kumar, S. H. R. Abdi, R. I. Kureshy, N. H. Khan, H. C. Bajaj, Appl. Catal. A, 2014, 486, 105-114.

[20] A. Osatiashtiani, A. F. Lee, M. Granollers, D. R. Brown, L. Olivi, G. Morales, J. A. Melero, K. Wilson, ACS Catal., 2015, 5, 4345-4352.

[21] A. Osatiashtiani, A. F. Lee, D. R. Brown, J. A. Melero, G. Moralese, K. Wilson, Catal. Sci. Technol., 2014, 4, 333-342.

[22] J. J. Kang, Y. X. Rao, M. Trudeau, D. Antonelli, Angew. Chem. Int. Ed. 2008, 47, 4896-4899.

[23] I. Dosuna-Rodriguez, C. Adriany, E. M. Y. Gaigneaux, Catal. Today, 2011, 167, 56-63.

[24] H. L. Li, A. J. Deng, J. L. Ren, C. Y. Liu, Q. Lu, L. J. Zhong, F. Peng, R. C. Sun, Bioresource Technol., 2014, 158, 313-320.

[25] G. Xiao, J. F. Zhou, X. Huang, X. P. Liao, B. Shi, RSC Adv., 2014, 4 4010-4019.
[26] D. R. Fernandes, A. S. Rocha, E. F. Mai, C. J. A. Mota, V. T. da Silva, Appl. Catal. A, 2012, 425-426, 199-204.

[27] M. K. Lam, K. T. Lee, A. R. Mohamed, Appl. Catal. B, 2009, 93, 134-139.

[28] Z. L. Li, R. Wnetrzak, W. Kwapinski, J. J. Leahy, ACS Appl. Mater. Interf., 2012, 4, 4499-4505.

[29] W. P. Ding, J. Li, K. Tao, RSC Adv., 2014, 4, 34161-34167.

[30] C. C. Huang, C. J. Yang, P. J. Gao, N. C. Wang, C. L. Chen, J. S. Chang, Green Chem., 2015, 17, 3609-3620.

[31] H. Zhao, P. P. Jiang, Y. M. Dong, M. F. Huang, B. L. Liu, New J. Chem., 2014, 38, 4541-4548.

[32] J. B. Joo, A. Vu, Q. Zhang, M. Dahl, M. F. Gu, F. Zaera, Y. D. Yin, ChemSusChem., 2013, 6, 2001-2008.

[33] G. D. Yadav, S. B. Kamble, Appl. Catal. A, 2012, 433-434, 265-274.

[34] J. E. Tabora, R. J. Davis, J. Am. Chem. Soc., 1996, 118, 12240-12241.

[35] Y. Y. Sun, L. N. Yuan, S. Q. Ma, Y. Han, L. Zhao, W. Wang, C. L. Chen, F. S. Xiao, Appl. Catal. A, 2004, 268, 17-24.

[36] T. Caillot, Z. Salama, N. Chanut, F. J. C. S. Aires, S. Bennici, A. Auroux, J. Solid State Chem., 2013, 203, 79-85.

[37] A. Kumar, A. Ali, K. N. Vinod, A. K. Mondal, H. Hegde, A. Menon, B. H. S. Thimmappa, J. Mol. Catal. A, 2013, 378, 22-29.

[38] Z. K. Zhao, X. L. Lin, R. H. Jin, Y. T. Dai, G. R. Wang, Catal. Sci. Technol., 2012, 2, 554-563.

[39] J. He, J. W. Chen, L. B. Ren, Y. Wang, C. Teng, M. Hong, J. Zhao, B. W. Jiang, ACS Appl. Mater. Interf., 2014, 6, 2718-2725.

[40] K. Saravanan, B. Tyagi, R. S. Shukla, H. C. Bajaj, Appl. Catal. B, 2015, 172-173, 108-115.

[41] S. K. Das, M. K. Bhunia, A. K. Sinha, A. Bhaumik, J. Phys. Chem. C, 2009, 113, 8918-8923.

\section{芳炔烯基化制烯基芳香化合物用硫酸化的介孔镧锆固体超强酸催化剂的 织构和酸性质调控研究}

\author{
赵忠奎”，手金凤，郭永乐，苗博元，王桂茹 \\ 大连理工大学化工与环境生命学部精细化工国家重点实验室, 辽宁大连 116024
}

摘要: 烯基芳香化合物作为重要的精细化学品及中间体在医药、染料、农药、香料、新型高分子材料、天然产品等化学 
工业领域占据显著地位. 芳香化合物与烯基化合物进行反应是该化合物的经典合成方法, 但其存在诸多缺陷: (1) 芳环需 要预活化, 如卤代、三氟甲磺酸取代等; (2) 产生氢卤酸和无机盐废物, 污染环境; (3) 原子经济性差. 如何高效绿色合成烯 基芳香化合物已引起国际学术界的极大兴趣.

近年来发现的芳香化合物与炔的烯基化, 亦称炔的氢芳化, 被认为是颇具应用前景的简单、清洁、原子经济的烯基芳 香化合物合成新路线. 与烯基芳香化合物的经典合成路线相比, 经由芳香化合物与炔的烯基化来合成该目标化合物具有 如下优点: (1) 芳环无需预活化; (2) 不产生氢卤酸和无机盐, 合成过程环境友好; (3) 原子经济性好 (100\%). 因此, 采用芳 香化合物与炔的烯基化路线来合成烯基芳香化合物得到了国际学术界的广泛关注.

芳香化合物与炔的烯基化反应主要经由两种路径: (1) 活化芳环, 形成 $\sigma$-芳基金属络合物; (2) 活化炔基, 形成烯基阳离 子. 活化芳环烯基化催化剂的研究主要集中在贵金属盐、贵金属配合物或有机金属. 采用贵金属或有机金属催化, 活性高、 选择性好, 但存在价格高、多需昂贵配体、分离和催化剂回收困难、操作条件苛刻等问题, 缺乏实用性. 酸催化活化炔基 是芳香化合物烯基化反应的另一途径. 酸催化芳烃烷基化已得以广泛而深入地研究, 并在化学工业中占据着突出的历史 地位, 但酸催化烯基化相关文献报道尚少. 相对于酸催化的烷基化, 烯基化面临更多挑战. 尽管如此, 成本低、实用性强的 酸催化烯基化路线仍得到了国际学术界的极大关注. 但是, 仍存在腐蚀设备、污染环境、催化效率差、收率低、催化剂分 离困难及炔聚合严重等不足之处. 因此, 开展清洁、高效、实用的新型烯基化固体酸催化剂的研究意义深远.

微孔沸石分子篎克服了液体酸所固有的上述缺点, 作为环境友好的固体酸催化剂在烷基化、酰基化等诸多反应中均得 到了广泛应用, 用于烯基化, 存在底物适用范围窄、催化效率低、选择性差和炔聚合严重的问题. 以介孔固体酸取代微孔 沸石分子篮并结合催化剂微结构和酸性质调控, 有望实现对反应底物和烯基化产品的扩散、炔的活化及芳烃与烯基阳离子 之间的碰撞过程进行调控, 从而解决现有固体酸催化该反应存在的问题.

我们开展了芳烃与炔烃的付-克烯基化制烯基芳香化合物用硫酸化的介孔镧锆固体超强酸催化剂的织构和酸性质调控 研究. 通过介孔镧锆复合氧化物的制备过程参数, 如模板剂和氨水的加入量、水热温度、水热时间的调节, 来调控硫酸化 的介孔镧锆固体超强酸催化剂的织构和酸性质, 进而调控固体酸的烯基化催化性能. 结果表明, 介孔镧锆复合氧化物的制 备过程参数对所制备的硫酸化的介孔镧锆固体超强酸催化剂的织构和酸性质影响显著, 需要合适的模板剂和氨水的加入 量、水热温度、水热时间, 才能获得适宜的织构和酸性质. 介孔镧锆复合氧化物的最佳制备条件为: 模板剂与金属离子摩 尔比 0.18 、氨水与金属离子摩尔比 16 、水热温度 $90{ }^{\circ} \mathrm{C}$ 、水热时间 $60 \mathrm{~h}$. 相对于研究组先前报道的硫酸化的介孔镧锆固体 超强酸催化剂, 经织构和酸性质调控优化的硫酸化的介孔镧锆固体超强酸催化剂的催化活性和稳定性均得以显著提升. 采用本文所构筑的固体酸催化剂, 用于不同芳香化合物的烯基化, 也展示出了良好的催化性能. 研究结果表明, 具有适宜 织构和酸性质的介孔固体酸用于芳香化合物与炔烃的烯基化, 来制备烯基芳香化合物, 具有很好的发展前景.

关键词: 介孔固体酸; 烯基化; 清洁合成; 烯基芳香化合物; 织构和酸性质; 调控

收稿日期: 2016-03-17. 接受日期: 2016-04-20. 出版日期: 2016-08-05.

*通讯联系人. 电话/传真: (0411)84986354; 电子信箱: zkzhao@dlut.edu.cn

基金来源: 国家自然科学基金 (21276041); 教育部新世纪优秀人才支持计划项目 (NCET-12-0079); 辽宁省自然科学基金 (2015020200); 中央高校基本科研业务费专项资金资助项目 (DUT15LK41).

本文的英文电子版由Elsevier出版社在ScienceDirect上出版(http://www.sciencedirect.com/science/journal/18722067). 